\title{
Management Graduates Employability (With a Special Reference to State Universities in Sri Lanka)
}

\author{
W.D.M.B.K. Dissanayake ${ }^{1}$ \\ ${ }^{1}$ Department of Business Management \\ Faculty of Business Studies \& Finance \\ Wayamba University of Sri Lanka \\ Kuliyapitiya \\ SRI LANKA \\ $\underline{\text { bimba@wyb.ac. } \mathrm{k}^{1}}$
}

\begin{abstract}
Unemployment among graduates is a burning problem in the Sri Lankan economy. It is argued that the degree programs have been confined to conventional subject areas and conventional teaching-learning methods. The private sector and even the public sector are more concerned with skills and attitudes rather than knowledge possessed by graduates. This research is specially focused on the implications of industrial training on bridging this competency gap among local university graduates. This study explores the implications of industrial training on the employability of the management graduates who are passing out from the state universities in Sri Lanka. Although a considerable amount of literature addresses employability skills, much of the information is theoretical and offers prescriptive advice. The paper presents findings of a survey that investigated graduates who went through industrial training and the substance implications of the training towards employability. The quantitative approach was used in this study where the findings were quantified and presented in a more precise manner. A total of 300 sample populations were selected for this study following the convenience sampling technique. Data were gathered through a survey using a Likert scale questionnaire. Survey data was analyzed using descriptive statistical tools such as mean, median, variance, and standard deviation. The findings suggest that there is a direct and significant implication from the industrial training towards the potential employability of the graduates. Further, the findings suggest that the chances of being successful in finding employment and sustainability will be based on the richness of the training that the graduate holds.
\end{abstract}

Keywords: Graduate, Industrial Training, Employability, Industry, Sri Lanka

\section{INTRODUCTION}

Education is a key determining factor in the prosperity and development of a country. One of the main objectives of the higher education sector in a country is to groom students to actively engaging in economic activities through pursuing successful careers. Contribution from the higher education sector is in the immense value of achieving the aforementioned 
objective. University education is the core of higher education and is expected to facilitate for higher intellectual needs of a community as in both academic knowledge and professional training aspects. Therefore, the university system of any country must be able to address the contemporary needs of a country through a well-organized curriculum. Ballantine (1997) describes universities as communities with overall academic programs, centralized physical settings, and an institute, which teaches the entire knowledge and spreads the knowledge.

As per university grants commission (UGC) statistics, the country's total undergraduate enrolment in universities and higher education institutes in 2015 was around 86,321 spreading among fifteen universities and ten higher education Institutes (UGC, 2015). This segment of students is known to be the finest intellect among Sri Lankan advanced level students and is the prospected prominent drivers of the country. These privileged few are the cream of the nation with all the potential to take the country to new heights (Hennayake, 2008). However, many students, who are privileged to enroll in university education, have to face numerous challenges especially at the end of graduation in seeking suitable employment.

The recent experience reveals that even talented graduates have to wait for a long time to be employed after graduation. Some graduates including management graduates are waiting to be employed by government recruitment schemes (Ariyawansa, 2008). Many of the graduates have passed out obtain a certificate, which does not help enough them to find suitable employment. Even if one of the main objectives of university education is to improve the skills of students to face the challenges in external society, they have to leave the university without having sufficient self-confidence and assurance for better employments (De Silva, 1977). The employability skills by graduates are essentially demonstrated through the various programs taken by graduates and university lecturers during the undergraduate degree programs (Wickramasinghe and Perera, 2010).

Under this circumstance, graduates' unemployment has become a severe problem in Sri Lanka during the last few decades. Figure 1 shows the employability percentages of the graduates by the university. There is an unemployment rate that varies between $57.1 \%-4.3 \%$ in all the universities. 


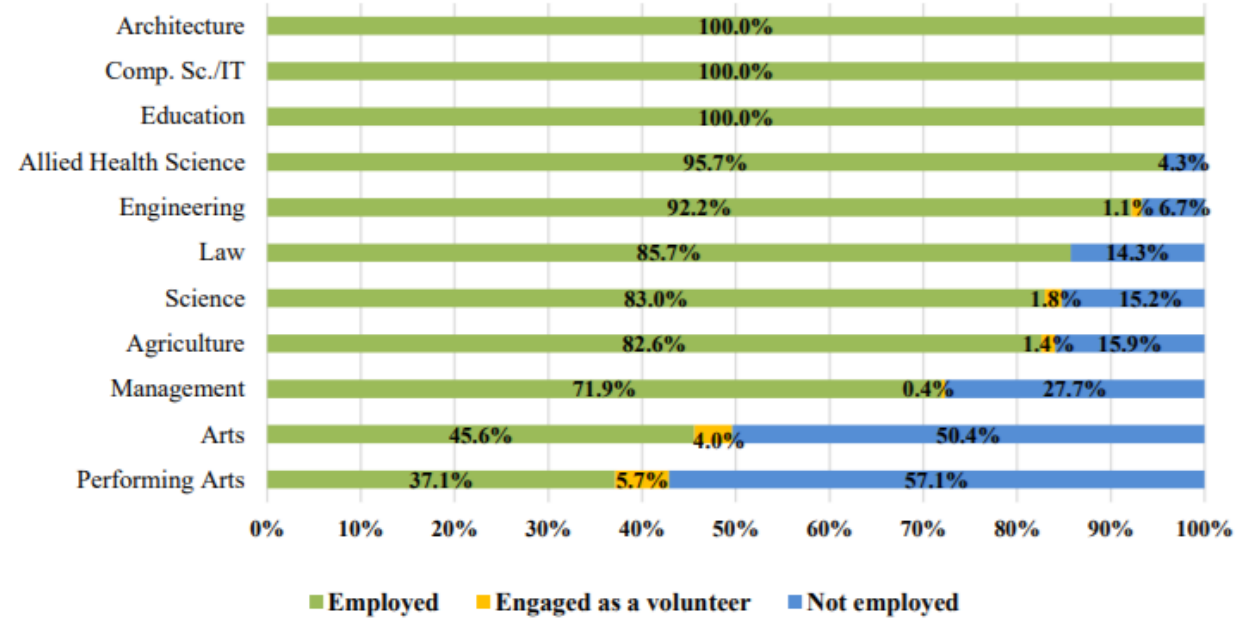

Figure 1. Employment Status by Academic Stream - State Universities

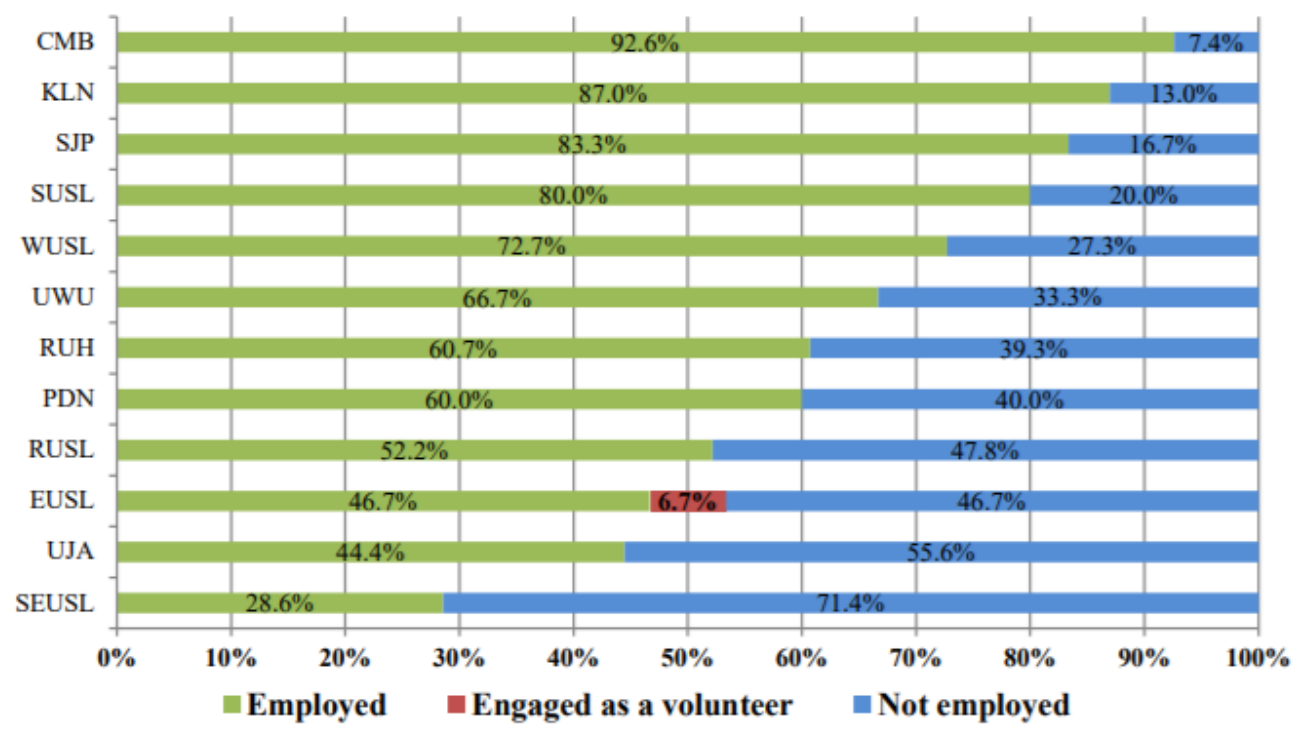

Figure 2. Employment Status by Academic Stream - Management

Figure 2 shows the employment status of the graduates by the management discipline. Percent employed is denoted the lowest of $28.6 \%$ and highest of $92.6 \%$. However, in the stream of Management, it is evident that there exists an unemployment rate of $27.7 \%$ which is a very crucial situation.

\section{Research Problem}

In Sri Lanka, the current education sector, particularly the higher 
education sector faces a challenging situation concerning the employability of graduates. Finding an employability opportunity in the private sector and the public sector organizations for university graduates is becoming a difficult task. Unemployment and underemployment of graduates became a widely criticized aspect in the higher education sector (Weligamage and Siengthai, 2003). This situation is more serious in the case of some graduates. There is a common problem among most Sri Lankan local university graduates as they are lack most of the skills required by the companies. The majority of the responsibility is imposed on local universities.

In many situations, the reality is that the qualification alone does not help enough to find a job because of the mismatch between the demand and the supply of the job market. Therefore, some graduates have to engage in irrelevant jobs mostly under low salaries while some of them have to be unemployed and wait for a long time mostly until the government provides opportunities. Such graduates will become a burden not only for their families but also to the whole country. The effects of this would have arisen as frustration, youth unrest, violence, and other forms of anti-social behaviors. Furthermore, the consequences of this would be prevailing in society as short term or/and long term social, cultural, economic, demographic, and political issues.

Unemployment among graduates is becoming a burning problem in today's Sri Lankan economy. It is argued that the degree programs have been confined to conventional subject areas and conventional teachinglearning methods. Furthermore, the graduates' incompetence is the fact that makes graduates less attractive. Also, without having a proper sense of the needs and wants of the job market, the mere production of graduates has intensified the problem. In a fast dynamic and globalized society, having only paper qualifications, which is highly limited to theoretical knowledge, is not adequate. The private sector, NGOs, and even the public sector are more concerned with skills and attitudes rather than knowledge possessed by graduates. To overcome those obstacles universities can adopt various types of methodologies. This research is specially focused on the usage of industrial training on bridging this competency gap among local university graduates.

Within this context, it is important to identify why graduates cannot find suitable jobs as soon as they pass out from universities. And why is the country's employment sector not capable to absorb such graduates into the development process? Therefore, the main objective of this paper is to focus on the implications of providing productive industrial training within the fourth academic year of their under graduation period as a mean of enhancing graduates' employability.

As a solution for this and with a view on further enhancing students' competencies some universities provide industrial training to their undergraduates in the final academic year/semester while some of the 
universities do not. Considering all the above-mentioned factors related to the current higher educational scenario the researcher thought to research how this industrial training implicate on the employability of the graduates who passed out from local universities in Sri Lanka to fill the vacuum of insufficient consideration given to this area by the majority of scholars especially within the Sri Lankan context.

Industrial training is a greater opportunity for students to gather relevant experience from the industry and therefore students can apply their theoretical knowledge that they have gained during the first three years at the universities. From the industry point of view: this is a very good opportunity for them to train and recruit suitable employees for the employment available in the future.

However, it is noted that very little attention being received by relevant parties and it is clear that the effort made by the universities to develop linkages between them and the industry has not yielded aspired results in ensuring the graduates' employability.

It was also found that industries have not been able to absorb those undergraduates even after the graduation of such trainees who have undergone training at the relevant organization. Therefore present research was designed to find solutions for the below-mentioned questions.

\section{Research Questions}

- What are the critical success factors triggering the employability of graduates?

- What are the implications of industrial training on the graduates' employability?

Furthermore, the research findings will be beneficial for different levels in the society as policymakers and the key decision-makers in the higher education ministry level, vital decision-makers in the private and public sector organizations, university grant commission, state university administrators, and the current and potential university undergraduates who are pursuing their academics.

\section{Literature Review}

Graduates should have the capability of steering the world of work and selfmanage the career-building process (Archer and Davison, 2008), and higher education institutions have a big contribution in developing that aforesaid capacity of a graduate. As a country's population attains a higher educational level, it adds to its skilled labor force. Universities are known to be centers of wisdom and capable of backing a country's innovation system (Esham, 2008). There is a strong linkage between knowledge and competitive advantage and planning for the future is the key to success. It was noted that the primary role of higher education is to guide and train the students through knowledge, skills, attitudes, and ability enhancement and empower them to pursue themselves as critical and reflective learners throughout their 
span of life (Harvey, 2000). However, it is established that the existence of a supply and demand mismatch for graduate employment in Sri Lanka is caused by the higher education system which is less relevant to prospects of employers in the private sector. This has hindered the employment opportunities which would have created for a substantial number of graduates (Ranasinghe, 1992).

Under this context, it seems that the university system is in a continuous quest in finding a solution to the amplifying unemployment problem of the country. Criticizing the responsibility of the university system regarding graduates' employability, De Silva (1977) further mentioned that it has tried to respond by hastily conceived ad-hoc solutions which have only aggravated the situation.

Gunawardana (1997) explains the relationship between education and employment. Generally, the graduates who followed job-oriented courses such as law, medicine, engineering, architecture, valuation, and accountancy could find jobs without having a longer waiting time compared to the other degree holders especially in the areas of social sciences and humanities. Ideally speaking academia and industry should share similar goals. The most common goals would include, understanding the employers' need, developing specific skills relevant to the market needs, training requirements, and top-level interaction between the two (Matlay and Rae, 2007). The academiaindustry interface could be defined as interactive and collaborative arrangement between academic institutions and business corporations for the achievement of certain mutually inclusive goals and objectives (Irfan and Ashita, 2005). The importance of the linkage between industry and higher education institutions cannot be underestimated. Quality of education surely hinges upon the active involvement of the business sector with higher educational institutions. Not only does this active cooperation and collaboration produce meaningful results in the form of real solutions to problems, but also boosts business performance besides enhancing education quality.

Universities - industry collaboration is the interaction between the higher education system and industry in a country to exchange knowledge and technology between both parties (Siegel, Waldman and Link, 2003). Collaboration provides the industry with how to have access to advance technology and know-how at a lower cost and with less inherent risk as universities possess a large pool of expertise (Esham, 2008). Beard (1994) suggested several recommendations to improve linkages between academia and industry, which include, a greater degree of collaboration between the two, real involvements with industry to give exposure of practical experiences to students, arranging guest speaker sessions, and encouraging faculty to undertake consultancy work.

As seen from the industry's point of view, collaboration with academia is needed because the industry lacks inhouse $\mathrm{R} \& \mathrm{D}$, limited finance, and 
shortening of the product life cycle. Universities also have shown interest to work closely with the industry to create funds to keep the $\mathrm{R} \& \mathrm{D}$ department humming. One important reason to bring academia and industry together is to gain access to students as potential future employees and to aid in product development (Siegel, Waldman, and Link, 2003; Ankrah and Omar, 2015).

Universities play three major roles within an innovation system. These include undertaking the general process of scientific research, partly producing knowledge, and providing major inputs for industrial innovation processes (Schartinger et al, 2002). Researchers outline several opportunities, for strengthening the academia-industry interface. For the academic community, it was suggested to bring the real world into the classroom or take the classroom into the real world; students need to be educated in international studies, stay connected to industry and continue to explore new research opportunities

For industry, it has been suggested that industry try offering more work opportunities to interested students and professors, build deeper relationships with students, and redistribute the funding. Both academia and industry expand collaboration, halt the impending identity crisis, expand the diversity of the design community and modify academic rewards structures to encourage collaboration (Wickramasinghe and Perera, 2010; Siegel, Waldman and Link, 2003; Ankrah, and Omar, 2015).

\section{Conceptual Framework}

Based on the above literature it was conceptualized the implication of industrial training on graduate employability as depicted in figure 3 which is presented below. It suggests that industrial training will root for gaining experience regarding the industrial world, motivation to work improves the practical know-how and enhance the general \& specific jobrelated skills which are required to perform a job better than an average person. Ultimately it influences to the employability of the graduate. On the other hand, a person who does not go through industrial training does not have the experience, de-motivated to do the tasks he/she is assigned with, do not equipped with practical knowhow, do not enhance skills which will assist to perform the job well \& finally headed to a low level of employability. The underlying argument of the research study has been illustrated below with the aid of a graphical illustration of the conceptual framework.

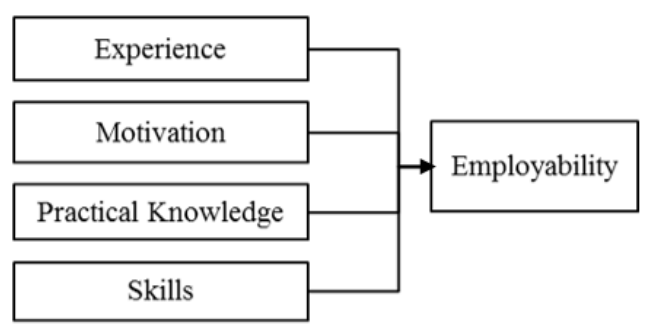

Figure 3. Conceptual Framework

\section{Hypothesis}

The objective of this study was to research whether there is a 
relationship between a graduates' employability \& industrial training that the student goes through. To find out whether there is any effect on the employability of graduates from the industrial training the hypothesis has been developed as follows.

H1: Experience gained from the training has an implication on the employability of management graduates of state universities.

$\mathrm{H} 2$ : Motivation has an implication on the employability of management graduates of state universities.

H3: Practical knowledge has an implication on the employability of management graduates of state universities.

H4: Skills acquired through training has an implication on the employability of management graduates of state universities.

\section{METHODS}

This study is primarily an empirical analysis using a quantitative approach, which is based on the primary data collected through a survey conducted by the researcher through a selfadministered Likert scale questionnaire. The questionnaire that was designed carried a detailed set of questions, to capture a wide range of information facilitating comprehensive research. The data collected through the survey were in
Table 1. Descriptive Statistics for Experience

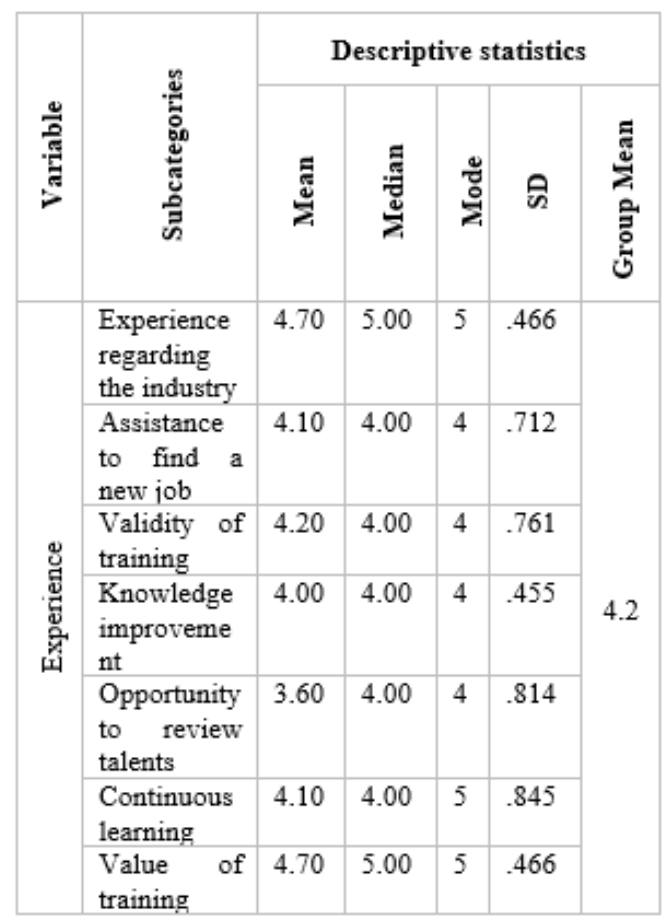

converted into numerical form and different views were descriptively analyzed to comprehend the magnitude of the issue.

The study population is the graduates who passed out from the state universities, by excluding the University of Moratuwa and University of visual arts \& performance studies, which does not offer any degree related to management discipline. The reference group had been determined as the graduates passed out from the national universities during the 2009-2012 
periods. A sample of 300 graduates has been selected from the population by using the convenience sampling technique considering the resource constraints as well as the convenience.

\section{RESULTS}

The data was collected from a sample survey which was conducted by a mean of structured Lickert scale questionnaire. Samples of 300 graduates' opinions were surveyed by giving 50 questions which cover four major areas of training.

In this section, the researcher analyzes each variable by using the Lickert scale to identify the influence of each variable on Industrial training upon the employability of the management graduates of Sri Lankan State Universities. There were 50 questions in the Questionnaire which represents a variable from each \& every question. The questionnaire surveyed about four main variables that affect employability through training known as Experience, Motivation, Skills, and Practical knowledge. Under the main four variables, some sub-variables collectively contribute to the findings of the magnitude of the main variable. Training experience refers to the experience the respondent gain regarding the industry he/she was engaged with by going through an on the job training through Industrial Training.

The standard deviation values for all the variables were less than 1 which indicates the respondents' actual responses were closer to the mean values. The group mean was 4.2 which agrees with the overall mean of training gave a good experience. Therefore as a whole, more than $90 \%$ of the graduates agree that the industrial training gave them a sound experience regarding the corporate world.

\section{Table 2. Descriptive Statistics for}

\section{Motivation}

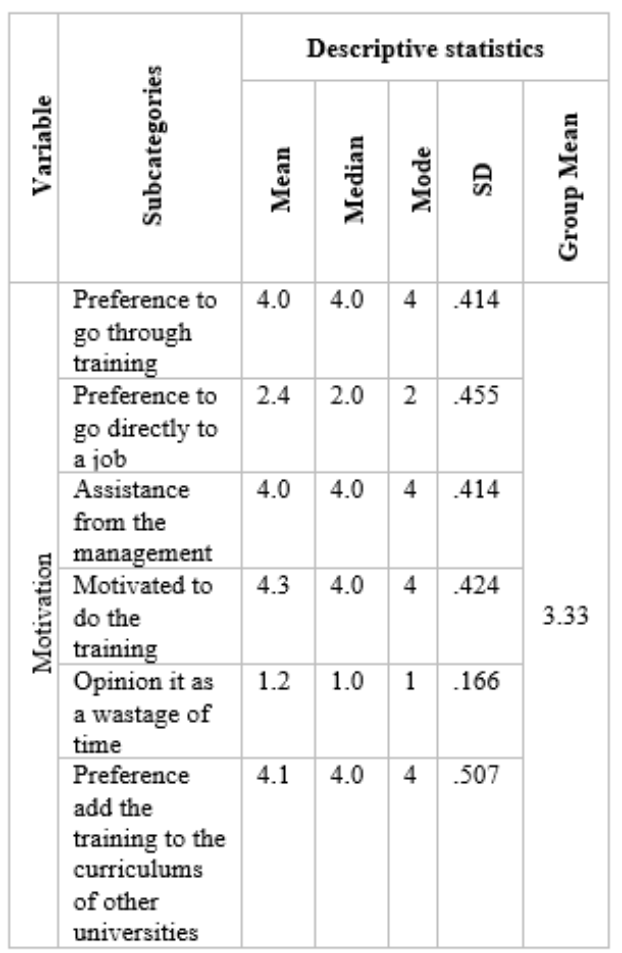

This variable was primarily considered about the degree of motivation gained by the graduates through industrial training. The objective is to measure the extent to which the training would enhance the motivational level of the candidate. The group mean was 3.33 which is as a whole the respondents were in between the agreement and disagreement of the opinion that the training tends to motivate them regarding the corporate world. 
Table 3. Descriptive Statistics for Skills

\begin{tabular}{|c|c|c|c|c|c|c|}
\hline \multirow{2}{*}{ 营 } & \multirow{2}{*}{ 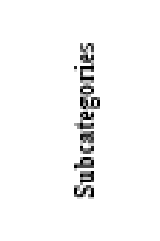 } & \multicolumn{5}{|c|}{ Descriptive statistics } \\
\hline & & 丞 & 瞣 & పัँ & คิ & 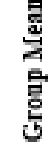 \\
\hline \multirow{11}{*}{ 号 } & $\begin{array}{l}\text { Improvement } \\
\text { of akills }\end{array}$ & 4.2 & 4.0 & 4 & .761 & \multirow{11}{*}{4.14} \\
\hline & $\begin{array}{l}\text { Improvement } \\
\text { of } \\
\text { communicati } \\
\text { on skills }\end{array}$ & 4.0 & 4.0 & 4 & .455 & \\
\hline & $\begin{array}{l}\text { Increase self } \\
\text { confidence }\end{array}$ & 4.2 & 4.0 & 4 & .407 & \\
\hline & $\begin{array}{l}\text { Easy } \\
\text { communicati } \\
\text { on with } \\
\text { others }\end{array}$ & 3.9 & 4.0 & 4 & .548 & \\
\hline & $\begin{array}{l}\text { Improvement } \\
\text { of business } \\
\text { writing skills }\end{array}$ & 4.2 & 4.0 & 4 & .610 & \\
\hline & $\begin{array}{l}\text { Leadership } \\
\text { skills } \\
\text { development }\end{array}$ & 4.1 & 4.0 & 4 & .548 & \\
\hline & $\begin{array}{l}\text { Improvement } \\
\text { of } \\
\text { presentation } \\
\text { gkills }\end{array}$ & 4.0 & 4.0 & 4 & .455 & \\
\hline & $\begin{array}{l}\text { Improvement } \\
\text { of time } \\
\text { management } \\
\text { skills }\end{array}$ & 4.2 & 4.0 & 4 & .610 & \\
\hline & $\begin{array}{l}\text { Enhancement } \\
\text { of } \\
\text { interpersonal } \\
\text { gkills }\end{array}$ & 4.3 & 4.0 & 4 & .651 & \\
\hline & $\begin{array}{l}\text { Enhance the } \\
\text { personality }\end{array}$ & 4.1 & 4.0 & 4 & .548 & \\
\hline & $\begin{array}{l}\text { Improvement } \\
\text { of analytical } \\
\text { gkills }\end{array}$ & 4.3 & 4.0 & 4 & .651 & \\
\hline
\end{tabular}

The skills refer to the soft skills which are needed to do a job effectively and efficiently. The variable was sub categorized into several soft skills as communication skills, business writing skills, leadership skills, presentation skills, time management skills and interpersonal skills. All the standard variance values and variance values were less than 1 . Therefore the actual responses have not deviated from the mean values in a significant amount. The group Mean was 4.1 which indicated the respondents agreed that the training leads to improve their soft skills.

Table 4. Descriptive Statistics for Practical Knowledge

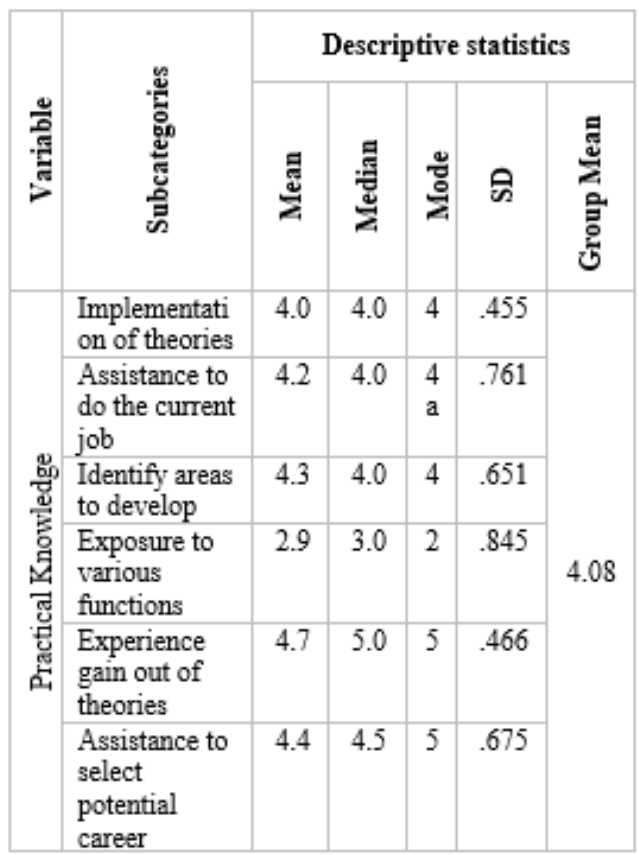

Practical knowledge is the knowledge gain apart from the theories and concepts. The know-how of the industry which is gained through the industrial training was measured from this part of the questionnaire. The group Mean was 4.08 which indicated that the respondents were agreed with the fact that they gain sound practical know-how of the industry through industrial training. Since the standard deviation values and variance values were less than 1 as per previous situations the actual values of the respondents' were not largely deviated from the Mean value. 
Based on the results of the descriptive statistical analysis the hypotheses $\mathrm{H} 1$, $\mathrm{H} 2, \mathrm{H} 3$, and H4 were accepted.

\section{DISCUSSION}

Training provides a sound experience regarding the corporate world (Beard, 1994). The majority of the respondents were able to get a widespreading experience regarding the industry from industrial training. The training each of them was gone through was a great help for finding a new job because through the training the respondents received a sound knowledge and a better understanding of the corporate world. Therefore it was easier for them to grab the new openings in the corporate world and be groomed enough to successfully handle the challenges which came on the way than those who do not go through training.

The training added more validity to the life of the candidate with the sound experience they obtained. The training contributes to improving the knowledge not only the knowledge regarding the industry but also contributes to the development of common sense.

Due to the training, the candidates were able to have a review of the talents they possessed so far and whether they accomplished the things what is required by the business world, since an average person does not have the chance to review their talents, trained personnel has more probability to get the chance of employable. But there is a contradictory finding also which leads a confusing situation, the opinions of $10 \%$ of the respondents were disagreement with the point, the reason behind it was the training schedule. With a weakly scheduled training period, the candidates would not have a chance to review their talents. In such a situation, even though the person has gone through industrial training he/she might face difficulties when finding employment. Industrial training would be one of the best periods to learn about the industry and its operations. That was confirmed from the survey. The candidates were able to continually learn throughout the training which became an advantage among the rest of the employers who do not go through training.

Through training, candidates were highly motivated to do engage in the job as in the training period they have a chance to first learn things and then to execute the operations. The high level of motivation which was developed throughout the training period would enhance their level of confidence therefore able to succeed in their future jobs.

\section{CONCLUSION}

The findings in compliance with Siegel, Waldman, and Link, 2003; Ankrah and Omar, 2015, confirms that industrial training must be added to every university curriculum irrespective of the disciplines because it gives the knowledge which cannot be taken from anywhere else. Every student must go through industrial training in the relevant field to get an extra edge since the industrial qualification is a major factor which would be considered in recruiting as 
an employee to any of the institution around the world.

Industrial training develops the soft skills of the candidates where they cannot obtain merely by studying the theoretical concepts. With the experience of working together with co-workers, management, and the entire stakeholders, the candidate blends with the corporate society well therefore it enhances their communication skills and interpersonal skills (Beard, 1994).

In the industry time management is a crucial factor for success, by getting training in the industry the candidates' time management skills improving and as a result, they have an edge in finding a job and being successful in it. Other critical soft skills as presentation skills, leadership skills, especially analytical skills will enhance during training therefore the graduate who has gone through industrial training stands far above the average.

With the experience and the shaped up skills the overall personality also lifts by providing the door opened for lots of opportunities in the industrial world.

The candidate has a chance to implement the theories which they have learned in the classroom and experience the real-world implications of the theories. Hence those who have gone through training were well aware of the theory as well as the practicability them.

The training experience provides assistance to do the potential jobs smoothly as the person is well aware of the work settings and adapted to the business world before they enter the job world after graduation. Most of the time during the training period candidates were not able to expose to all the functional areas but they have a chance to gain sound knowledge regarding them.

In summary of all the candidates who have gone through industrial training within their final year of the university are found more competent, wellgroomed, and well prepared to accept the challenges that come on their way and able to grab the most suitable and enduring employable opportunities. Therefore, the null hypothesis is rejected and the alternative hypothesis is accepted and the conclusion can be made as according to the research study findings it can be concluded that the Industrial training enhances the employability of the graduates.

\section{REFERENCES}

Ankrah, S., and Omar, A. T., 2015. Universities-industry

collaboration: A systematic review. Scandinavian Journal of Management, 31(3), pp 387-408.

Archer, W., and Davison, J., 2008. Graduate employability. The council for industry and Higher Education.

Ariyawansa, R. G., 2008. Employability of graduates of Sri Lankan universities. Sri Lankan Journal of Human Resource Management, 1(2). 
Ballantine J., 1997. The Sociology of Education: A Systematic Analysis, 4th Edition,Prentice Hall Inc, USA.

De Silva W., 1977. The Current Scene and Emerging Trends in Sri Lanka, the Universities, Education and Socio Economic Development of Sri Lanka, Sri Lanka Foundation Institute, Colombo,

employment", Tertiary Education and Management, Vol. 6, pp. 3-17.

Esham, M., 2008. Strategies to develop university-industry linkages in Sri Lanka. National Education Commision Sri Lanka Study Series No. 4 (2007)

Gunawardena C., 1997. What Employers' Look in University Graduates, Economic Review, People's Bank, Colombo, Vol. 22, No. 10 Jan pp 19-22.

Harvey, L., 2000. New realities: The relationship between higher education and employment. Tertiary Education \& Management, 6(1), pp.3-17.

Hennayake, S., 2008. The Fundamental Threat to Sri Lankan University Education. Asian Tribune, 20 Retrieved August 16, 2017, from Asian Tribune: http://www.asiantribune.com/?q= node/14294

Rizvi, I.A. and Aggarwal, A., 2005, January. Enhancing student employability: Higher education and workforce development.
In Proceedings of the 9th Quality in Higher Education Seminar, Birmingham, UK.

Matlay, H., and Rae, D., 2007. Connecting enterprise and graduate employability. Education+ Training.

Ranasinghe, S.W., 1992. Human resource development in Sri Lanka: present trends and future perspectives, In S. Salleh and S.B. Gurung (Eds.), Human Resource Development in South Asia. Malaysia: Asian and Pacific Development Centre.

Schartinger, D., Rammer, C., Fischer, M.M., and Frohlich, J., 2002. Knowledge interactions between universities and inudstry in Austria: sectoral patterns and determinants. Research Policy, 31, 3, pp 303-328.

Siegel, D. S., Waldman, D., and Link, A., 2003. Assessing the impact of organizational practices on the relative productivity of university technology transfer offices: an exploratory study. Research policy, 32(1), pp 27-48.

University Grants Commission., 2015. Sri Lanka University Statistics 2015. Colombo: University Grants Commission.

Weligamage, S., and Siengthai, S., 2003. Employer needs and graduate skills: the gap between employer expectations and job expectations of Sri Lankan university graduates. In 9th 
International conference on Sri Lanka Studies. Matara, Sri Lanka.

Wickramasinghe, V., and Perera, L., 2010. Graduates', university lecturers' and employers' perceptions towards employability skills. Education+ Training, 52(3), pp 226-244. 